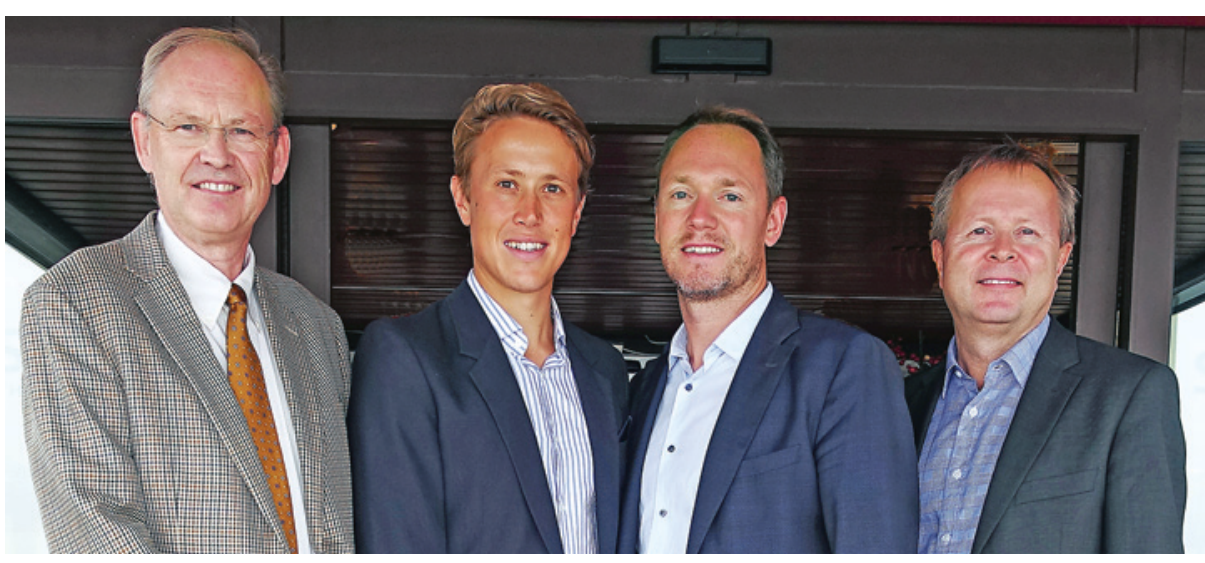

Fra venstre Geir Christensen, Peder Myhre, Helge Røsjø og Torbjørn Omland. Foto: Roy Trondsen

\title{
Peptid viktig prediktor hos kritisk syke
}

Secretonevrin er et peptid som regulerer kalsiumomsetting i hjerteceller. Konsentrasjonen av secretonevrin kan gi bedre risikoprediksjon ved både alvorlig infeksjon og akutt respirasjonssvikt.

Pasienter på intensivavdeling med respirasjonssvikt eller alvorlig infeksjon har høy dødelighet. Det er derfor ønskelig å finne biomarkører som raskt kan gi informasjon om prognose.

Peptidet secretonevrin produseres i nevroendokrint vev og myokard. Tidligere studier har vist at secretonevrinkonsentrasjon i blodbanen gir prognostisk informasjon ved akutt hjertesvikt og hos pasienter med hjertestans (1). En norsk forskergruppe ønsket derfor, i samarbeid med finske kollegaer, å undersøke prognostisk betydning av secretonevrin hos pasienter med annen form for kritisk sykdom.

De fant først at secretonevrin gir tilleggsinformasjon til etablerte risikoparametere hos pasienter med alvorlig sepsis eller septisk sjokk, og validerte så disse funnene hos pasienter med infeksjon. Denne studien ble publisert i 2015 i Critical Care Medicine (2), et ledende tidsskrift innen intensivmedisin. I en senere studie, som nylig ble publisert i Clinical Chemistry (3), fant forskerne ut at secretonevrin også kan gi prognostisk informasjon hos pasienter med akutt respirasjonssvikt dersom denne er relatert til hjerte- og karsykdom.

- Vi fant at secretonevrin ga tilleggsinformasjon til etablerte risikoparametere både hos pasienter med sepsis og hos pasienter med kardiovaskulær årsak til akutt respirasjonssvikt, sier Helge Røsjø ved Akershus universitetssykehus, som leder den norske forskningsgruppen. Secretonevrin ser altså ut til å forbedre risikoprediksjon hos kritisk syke pasienter med myokarddysfunksjon.

- Våre funn støtter tidligere resultater og danner grunnlag for utvidet bruk av secretonevrin som prognostisk markør, sier Røsjø, som har flere ideer til fremtidig forskning på dette spennende peptidet.

\section{Forskergruppen}

Cardiothoracic Research Group ved Akershus universitetssykehus og Institutt for eksperimentell medisinsk forskning ved Oslo universitetssykehus, Ullevål, har i lengre tid samarbeidet om å studere secretonevrin som biomarkør. Arbeidet ledes av Helge Røsjø og har foregått i nært samarbeid med leder av Cardiothoracic Research Group, Torbjørn Omland, og leder av Senter for hjertesviktforskning ved Universitetet i Oslo, Geir Christensen. Stipendiat Peder L. Myhre ved Akershus universitetssykehus er førsteforfatter på artikkelen i Clinical Chemistry.

Arbeidet med secretonevrin er et eksempel på forskningsdrevet innovasjon, der hovedforfatterne har patent på anvendelsen av secretonevrin som biomarkør gjennom sine arbeidsgivere. Det norske bioteknologiselskapet CardiNor er etablert for å utvikle secretonevrin til klinisk bruk. Arbeidet har vært støttet økonomisk av Akershus universitetssykehus, Norges forskningsråd, Helse Sør-Øst, Universitet i Oslo, Anders Jahres fond og K.G. Jebsen-stiftelsen.

\section{Ragnhild Ørstavik}

Tidsskriftet

\section{Litteratur}

1. Ottesen AH, Louch WE, Carlson CR et al. Secretoneurin is a novel prognostic cardiovascular biomarker associated with cardiomyocyte calcium handling. J Am Coll Cardiol 2015; 65: 339-51.

2. Røsjø H, Stridsberg M, Ottesen AH et al. Prognostic value of secretoneurin in critically ill patients with infections. Crit Care Med 2016; 44: 1882-90.

3. Myhre PL, Ottesen AH, Okkonen M et al. Prognostic value of secretoneurin in patients with acute respiratory failure: data from the FINNALI Study. Clin Chem 2016; 62: 1380-9

Publisert først på nett.
Ordforklaringer

Biomarkør: Biologisk substans som er objektivt målbar og som reflekterer en fysiologisk eller patofysiologisk prosess eller en terapeutisk intervensjon

Intracellulær kalsiumhåndtering i hjerteceller: Hjertemuskelcellenes sammentrekninger (kontraksjoner) er regulert av ioneflukser over cellemembranen og inn og ut av sarkoplasmatisk retikulum. Kalsium er et sentralt ion i denne sammenheng, og frisetting av kalsium er derfor strengt regulert i hjertemuskelcellene. Ved skade eller dysfunksjon i hjertemuskulaturen kan reguleringen være endret slik at mer kalsium frisettes i diastolen, noe som øker risikoen for ventrikulær arytmi og død. Secretonevrin ser ut til å motvirke diastolisk kalsiumfrisetting både i friske celler og i celler fra hjertesviktindivider.

Akutt respirasjonssvikt: Akutt respirasjonssvikt ble i FINNALI-studien definert som behov for invasiv eller ikke-invasiv respirasjonsstøtte over seks timer, uansett årsak til respirasjonssvikt.

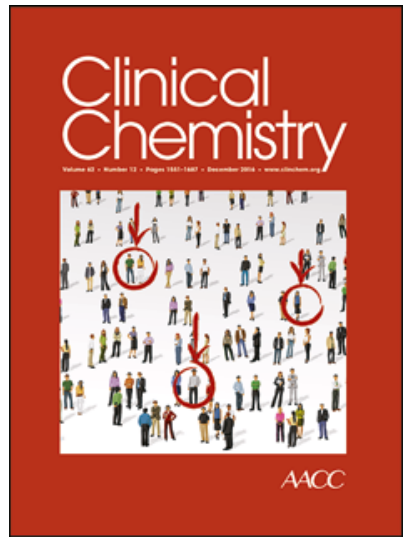

Resultater fra FINNALI-studien ble publisert i Clinical Chemistry i oktober 2016 